significant changes. We therefore agree with Chai et al. (1968) that as many criteria as possible need to be studied in a long-term assessment of asthmatic patients and that single, infrequent observations are of limited value.

The symptoms of house-dust allergy tend to fluctuate over the course of a year (Voorhorst et al., 1967), and the possibility that the improvement in our mite-treated group could be due to this was considered. But since no similar improvement occurred in the patients in the control group over the same period it was concluded that seasonal variation was not a significant factor. Furthermore, patients who had other seasonal allergies which could confuse the results were carefully excluded from the trial. We had no information about the mite content of the house dust in the patients' homes, but no patients moved house, installed central heating, or noticeably altered their environment in any other way during the trial.

Commercial extracts of $D$. pteronyssinus for hyposentitizing treatment are unavailable. However, the more easily cultured D. culinae seems to have antigenic properties similar to those of $D$. pteronyssinus and it is probable that similar results would be obtained with it. Indeed, Munro-Ashman et al. (1970) reported successful treatment in an uncontrolled series of patients with $D$. culinae extract.
We have concluded from this trial that hyposensitizing treatment with $D$. pteronyssinus extract in patients with housedust allergy is worth while and can offer considerable relief from their perennial asthma.

I am indebted to Dr. Kate Maunsell, who made the extracts. I thank Dr. R. S. Bruce Pearson and Dr. P. Hugh-Jones for permission to study patients under their care and for their helpful criticism. I am grateful to Miss Irene Renton for secretarial assistance and to Mr. M. Curwen, of Guy's Hospital, for help with the statistical aspects of this study.

\section{References}

British Tuberculosis Association (1968). British Medical fournal, 3, 774. Brown, H. M., and Filer, J. L. (1968). British Medical fournal, 3, 646. Chai, H., Purcell, K., and Brady, K. (1968), fournal of Allergy, 41, 23. McAllen, M. K., (1961). Thorax, 16, 30

McAllen, M. K., Assem, E. S. K., and Maunsell, K. (1970). British Medical fournal, 2, 501

Maunsell, K., Wraith, D. G., and Cunnington, A. M. (1968). Lancet, 1, 1267.

Munro-Ashman, D., et al. (1970). Exerpta Medica (Amsterdam) International Congress Series, No. 211, p. 139.

Pepys, J., Chan, M., and Hargreave, F. E. (1968). Lancet, 1, 1270.

Voorhorst, R., Spieksma, F. T. M., Varekamp, H., Leupen, M. J., and Lyklema, A. W., (1967). Fournal of Allergy, 39, 325.

\title{
Metabolic Responses to Oral Glucose in the Kalahari Bushmen
}

\author{
B. I. JOFFE, W. P. U. JAĆKSON, M. E. THOMAS, \\ R. ZAMIT \\ M. G. TOYER, P. KELLER, \\ B. L. PIMSTONE,
}

British Medical fournal, 1971, 4, 206-208

\section{Introduction}

The Bushmen are believed to constitute a distinct ethnic group, nowadays virtually confined to the Kalahari wastelands of Southern Africa. Physical differences from the neighbouring Negroid peoples are well described, with characteristic facial features and body build (see Fig.). They live by hunting game and collecting wild vegetation ("veldkos"), certain species of which seem to have high nutritive value (Wehmeyer et al., 1969), though their dietary habits are such that periods of semistarvation give way to episodes of overindulgence (BronteStewart et al., 1960).

Isolated biochemical studies in the Bushmen have shown distinctive patterns of serum proteins (Bronte-Stewart et al., 1960) and lipids (Miller et al., 1968), attributed to environmental rather than genetic influences, but little data exist on, potentially, one of the most intriguing metabolic aspects of all-namely, their capacity to dispose of and their hormonal response to an oral carbohydrate load. The following study was primarily undertaken in an attempt to answer this question.

\section{Subjects and Methods}

In October 1970 an expedition was made to the Dobe area in the north-western region of Botswana, where a group of !Kung Bushmen had congregated. They were all participating in the Harvard University Bushmen Project and consequently were not unaccustomed to contact with white research workers or venepuncture procedures. Fifteen apparently healthy adult members of the group were chosen for the study and a simple explanation of the intended investigation was given (by a member of the university team assisting our party). Various pertinent physical characteristics of the selected stibjects are 


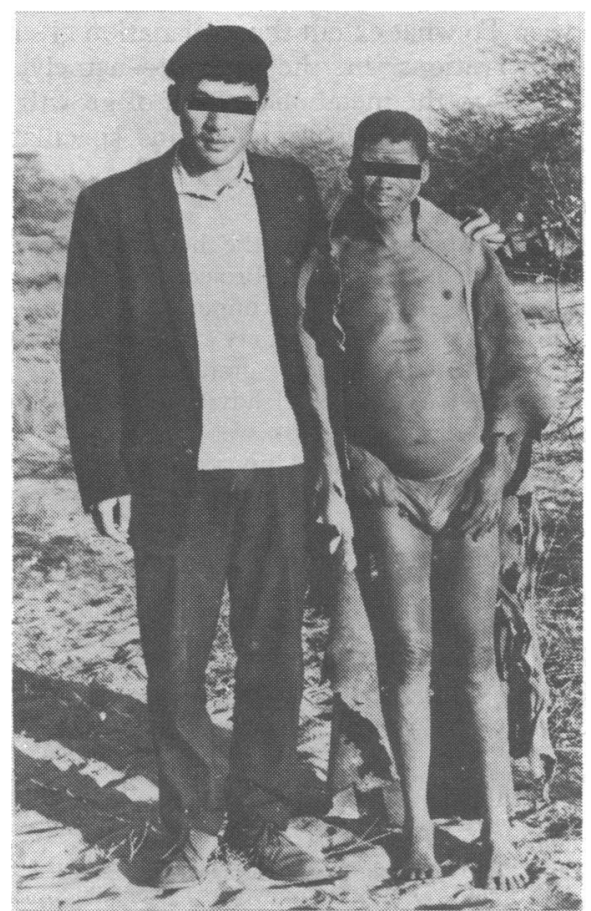

Male Bushman standing next to a subject who is $168 \mathrm{~cm}$ tall.

given in Table I. Since an overnight fast would probably have been broken (owing to the almost continuous eating pattern of the Bushmen when food is available), we performed tests in the afternoon, after four hours of observed rest and fasting. At the end of this period a venous blood sample was obtained from each patient and $50 \mathrm{~g}$ of glucose was given by mouth. Further venous blood samples were collected at 60 and 120 minutes thereafter. During this two-hour period continued observation was maintained.

TABLE I-Pertinent Physical Characteristics (Mean and Range) of Bushmen and Control Subjects Studied

\begin{tabular}{|c|c|c|c|c|c|}
\hline Group & No. & $\begin{array}{l}\text { Age in } \\
\text { Years* }\end{array}$ & Height $(\mathrm{cm})$ & Weight (kg) & $\begin{array}{c}\text { Ideal Body } \\
\text { Weight } \dagger(\%)\end{array}$ \\
\hline $\begin{array}{l}\text { Bushmen: } \\
\text { Males .. } \\
\text { Females } \\
\text { Controls .. }\end{array}$ & $\begin{array}{r}8 \\
7 \\
10\end{array}$ & $\begin{array}{l}40(25-50) \\
40(15-70) \\
28(18-45)\end{array}$ & $\begin{array}{l}158(154-161) \\
145(138-156) \\
172(155-190)\end{array}$ & $\begin{array}{l}46(41-50) \\
38(27-49) \\
65(42-82)\end{array}$ & $\begin{array}{l}90(80-98) \\
96(76-120) \\
97(88-105)\end{array}$ \\
\hline
\end{tabular}

*Assessed by their physical appearance and an "events calendar."

†Adapted from Metropolitan Life Insurance Company Statistical Bulletin (1959)

The samples were placed in heparinized tubes containing aprotinin (Trasylol), immediately separated by means of a battery-operated centrifuge, and the plasma was kept in the freezing compartment of a mobile gas refrigerator. They were packed in dry ice during the flight back to Cape Town.

Plasma glucose was measured on the Autoanalyzer by the modified ferricyanide method of Hoffman (1937). Radio- immunoassay techniques were used to determine plasma insulin (Hales and Randle, 1963) and growth hormone (Morgan and Lazarow, 1963) levels. Plasma proteins were measured electrophorectically on the fasting samples.

For comparison the plasma glucose, insulin, and growth hormone responses to a $50-\mathrm{g}$ oral glucose load in 10 non-obese healthy white controls (six males and four females) aged 18 to 45 years were used. These tests were also performed in the afternoon, after a four-hour fast, to obviate any discrepancies that might have arisen because of the diurnal variation in oral glucose tolerance (Jarrett and Keen, 1970).

\section{Results}

The results of the plasma glucose and insulin responses in the 15 Bushmen and 10 control subjects after oral glucose are summarized in Table II. Mean glucose levels were higher in the Bushmen at all stages, with significant differences at 0 and 120 minutes. Indeed, by lax criteria of evaluation (Jackson et al., 1970), their mean two-hour post-glucose level of $121 \mathrm{mg} /$ $100 \mathrm{ml}$ could be regarded as falling within the "diabetic" range. Conversely, the Bushmen exhibited insulinopenia throughout the test, and this was significant at 0 and 60 minutes. Calculation of the "insulinogenic" indices for the two groups served to accentuate the impaired insulin production occurring in the Bushmen. There was no significant differences in glucose or insulin values between the male and female Bushmen subgroups.

Growth hormone responses are outlined in Table III. Fasting plasma growth hormone levels showed no significant difference between the Bushmen and control subjects, and in both instances there was prompt suppression to near zero concentrations after glucose administration.

TABLE III-Mean ( + S.E. of Mean) Growth Hormone Responses in the Bushmen and Control Groups during Glucose Tolerance Test

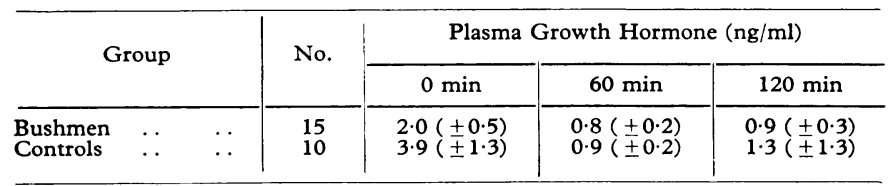

Finally, measurement of plasma proteins in the fasting samples of the Bushmen gave a mean total value of $7.6( \pm 0.3)$ $\mathrm{g} / 100 \mathrm{ml}$, with a mean albumin fraction of $3 \cdot 7( \pm 0 \cdot 2) \mathrm{g} / 100 \mathrm{ml}$. Corresponding values in the controls were $6 \cdot 3( \pm 0 \cdot 3)$ and $4 \cdot 1$ $( \pm 0 \cdot 4) \mathrm{g} / 100 \mathrm{ml}$.

\section{Discussion}

In the light of observations suggesting an inverse correlation between the degree of sophistication of population groups and their ability to metabolize effectively an oral glucose load (Rubenstein et al., 1969; Jackson, 1970), the relative carbohydrate intolerance of our primitive Bushmen subjects is at first glance rather surprising. Since it was impossible to ensure

TABle II-Mean ( \pm S.E. of Mean) Plasma Glucose and Insulin Responses of Bushmen and Control Subjects during 50-g Oral Glucose Tolerance Test

\begin{tabular}{|c|c|c|c|c|c|c|c|c|c|c|}
\hline \multirow{2}{*}{\multicolumn{2}{|c|}{ Group }} & & \multirow{2}{*}{ No. } & \multicolumn{3}{|c|}{ Plasma Glucose (mg/100 ml) } & \multicolumn{3}{|c|}{ Plasma Insulin $(\mu \mathrm{U} / \mathrm{ml})$} & \multirow{2}{*}{$\begin{array}{l}\text { Insulinogenic Index } \\
\text { Insulin } \Delta \\
\text { Glucose } \Delta\end{array}$} \\
\hline & & & & $0 \min$ & $60 \mathrm{~min}$ & $120 \mathrm{~min}$ & $0 \mathrm{~min}$ & $60 \mathrm{~min}$ & $120 \mathrm{~min}$ & \\
\hline $\begin{array}{l}\text { Bushmen } \\
\text { Controls }\end{array}$ & $\ldots$ & $\therefore$ & $\begin{array}{l}15 \\
10\end{array}$ & $\begin{array}{l}95( \pm 2) \\
85( \pm 2)\end{array}$ & $\begin{array}{l}169( \pm 11) \\
142( \pm 7)\end{array}$ & $\begin{array}{l}121( \pm 7) \\
101( \pm 6)\end{array}$ & $\begin{array}{l}10( \pm 1) \\
15( \pm 1)\end{array}$ & $\begin{array}{l}33( \pm 5) \\
63( \pm 9)\end{array}$ & $\begin{array}{l}20( \pm 3) \\
30( \pm 5)\end{array}$ & $\begin{array}{l}0.17 \\
0.35\end{array}$ \\
\hline Significance & $\ldots$ & $\ldots$ & $\ldots$ & $P<0.05$ & N.S. & $P<0.05$ & $\mathrm{P}<0.01$ & $\mathrm{P}<0.01$ & N.S. & $P<0.001$ \\
\hline
\end{tabular}

$\Delta=$ Calculated area under tolerance curve. 
an adequate carbohydrate intake among the Bushmen for some days before testing (nor did we want to alter their usual dietary habits) we were initially tempted to attribute the findings to a form of "starvation diabetes." However, several features mitigated against this possibility: a retrospective dietary history (M. J. Konner, personal communication, 1971) indicated that the Bushmen, in fact, consumed fairly large amounts of carbohydrate-rich vegetable food during the week before testing; their mean fasting plasma glucose level was raised rather than low; their pattern of insulin secretion was not sluggish and persistent (Tzagournis and Skillman, 1970); nor did their mean plasma albumin level suggest severe protein undernutrition.

Was the unusual diet of the Bushmen per se responsible for their impaired glucose tolerance and subnormal insulin release? Consumption of large amounts of mannoheptulose (occurring most abundantly in the avocado), for example, will block insulin release, with resultant hyperglycaemia (Nutrition Reviews, 1971), but no information is available concerning its content in Bushmen "veldkos."

A pronounced stress reaction at the time of the investigation could have produced a similar metabolic pattern (Jackson et al., 1970), but as none of the primitive subjects became overtly distressed during the test-a fact supported by their normal fasting growth hormone levels-this, too, seemed an unlikely explanation. Consideration was also given to the hypothesis that the significant impairment of insulin secretion reflected a degree of beta cell failure (or adaptation) induced by a variety of unfavourable environmental (and/or genetic) factors to which the Bushmen have been exposed.

Finally, the apparent similarity between certain of our results and those reported in the Central African pygmies by Merimee et al. (1968, 1969) and Rimoin et al. (1969) are of interest. Not only is the average height and weight of the two groups comparable but the pygmies also manifest abnormal glucose tolerance curves in some instances, significant postglucose insulinopenia, and normal, suppressable, basal growth hormone levels. To what extent the explanation given to account for these observations in the pygmy-namely, end-organ unresponsiveness to the metabolic effects of growth hormonecan be applied to the Bushmen, remains speculative for the moment.

It is a pleasure to acknowledge the help given by members of the Harvard University Kalahari Project, especially Professor I. DeVore and Mr. and Mrs. M. J. Konner. The chemical pathology department of Cape Town University Medical School performed the protein determinations. We are grateful to Drs. Trefor Jenkins and $H$. C. Seftel for their helpful advice and criticisms. Valuable help in preparing the manuscript was provided by Mrs. R. E. Joffe and the Witwatersrand University Medical Photography Unit. The study was financed, in part, by the South African Medical Research Council.

\section{References}

Bronte-Stewart, B., Budtz-Olsen, O. E., Hickley, J. M., and Brock, J. F. (1960). South African fournal of Laboratory and Clinical Medicine, 6, 187. 1960). S., and Randle, P. J. (1963). Biochemical fournal, 88, 137.

Hales, C. N., and Randle, P. J. (1963). Biochemical fournal, 88,

Hoffman, W. S. (1937). Fournal of Biological Chemistry, 120, Jackson, W. P. U. (1970). Acta Diabetalogica Latina, 7, 361 .
Jackson, W. P. U., Vinik, A. I., Joffe, B. I., Sacks, A., and Edelstein, I. (1970). South African Medical Fournal, 44, 1283.
arrett, R. J., and Keen, H. (1970). British Medical Fournal, 4, 334.

Merimee, T., J., Rimoin, D. L., Rabinowitz, D., Cavalli-Sforza, L. L., and McKusick, V. A. (1968). Transactions of the Association of American Physicians, 81, 221.

Merimee, T. J., Hall, J. D., Rimoin, D. L., and McKusick, V. A. (1969). Lancet, 1, 963.

Miller, K., Rubenstein, A., and Astrand, P. O. (1968). Archives of Internil Medicine, 121, 415.

Morgan, C. R., and Lazarow, A. (1963). Diabetes, 12, 115.

Nutrition Reviews, 1971, 29, 126.

Rimoin, D. L., Merimee, T. J., Rabinowitz, D., Cavalli-Sforza, L. L., and McKusick, V. A. (1969). New England fournal of Medicine, 281, and $M 83$.

Rubenstein, A. H., Seftel, H. C., Miller, K., Bersohn, I., and Wright, A. D. (1969). British Medical fournal, 1, 748.

Tzagournis, M., and Skillman, T. G. (1970). Metabolism, 19, 170

Wehmeyer, A. S., Lee, R. B., and Whiting, M. (1969). South African Medical fournal, 43, 1529.

\section{PRELIMINARY COMMUNICATIONS}

\section{Nephrotic Syndrome in Monkey Infected with Human Quartan Malaria}

\author{
A. VOLLER, C. C. DRAPER, TIN SHWE, \\ M. S. R. HUTT
}

British Medical fournal, 1971, 4, 208-210

\section{Summary}

A splenectomized aotus monkey infected with human quartan malaria (Plasmodium malariae) developed oedema and proteinuria. Histological examination revealed a generalized diffuse glomerulonephritis and immunofluorescent staining showed granular deposits of $\operatorname{IgM}$ in the glomeruli. The

Nuffield Institute of Comparative Medicine, the Zoological Society of London, London N.W.1

A. VOLLER, D.SC., Senior Lecturer

London School of Hygiene and Tropical Medicine, London W.C.1

C. C. DRAPER, D.M., D.P.H., Senior Lecturer

TIN SHWE, M.B., B.S., D.C.M.T., Research Assistant

St. Thomas's Hospital Medical School, London S.E.1

M. S. R. HUTT, M.D., F.R.C.P., Professor of Geographic Pathology pathological picture resembled that shown by human patients with the quartan malaria nephrotic syndrome.

\section{Introduction}

The association between Plasmodium malariae infection and the nephrotic syndrome has now been convincingly demonstrated in several areas of Africa (Gilles and Hendrickse, 1963; Kibukamusoke, Hutt, and Wilks, 1967), and the suggestion of Hendrickse and Gilles (1963) that the pathological picture might be the result of damage to the kidney by immune complexes has been shown to be correct as recent immunofluorescent observations (Allison et al., 1969; Ward and Kibukamusoke, 1969; Houba, Allison, Adeniyi, and Houba, 1971) have shown the presence of complexes in the kidneys of affected children.

Experimental work in the past has been hampered by the absence of a suitable animal model, and it is only recently that $P$. malariae has been adapted to a convenient primate, Aotus trivirgatus (Geiman and Siddiqui, 1969). The present communication describes the development of nephrotic syndrome in an aotus monkey infected with $P$. malariae.

\section{Materials and Methods}

The strain of Plasmodium malariae of human origin was obtained from Dr. R. Ward, of the Walter Reed Army Institute 